\title{
Primary production of Cymodocea nodosa in the Gulf of Trieste (Northern Adriatic Sea): a comparison of methods
}

\author{
Peter Peduzzi ${ }^{1}$, Aleksandar Vukovi ${ }^{2}$ \\ ${ }^{1}$ Institute of Zoology, University of Vienna, Althanstr. 14, A-1090 Vienna, Austria \\ ${ }^{2}$ Marine Biology Station Piran, Cesta JLA 65, YU-66330 Piran, Yugoslavia
}

\begin{abstract}
Net primary production of Cymodocea nodosa, a common seagrass in the Mediterranean Sea, was monitored in the Gulf of Trieste using 3 techniques. Production yields obtained by a method based on changes in biomass and leaf export, as indicated by the presence of leaf scars, were compared with 2 other approaches, a marking technique and the oxygen evolution in situ. In August-September, maximum total standing biomass at 3 stations ranged between 323 and $1020 \mathrm{~g}$ dry wt $\mathrm{m}^{-2}$. At the shallowest station, ca $88 \%$ of total biomass was below ground, compared to $61 \%$ at deeper stations. Leaf area indices varied throughout the growing season between 0.12 and 7.24 , indicating a distinct seasonal pattern in leaf production. On average up to 10 leaves were produced shoot ${ }^{-1} \mathrm{yr}^{-1}$; export rates of leaf material were highest in summer. Leaf production, as estimated by the leaf scar and marking techniques, ranged from 356 to $692 \mathrm{~g}$ dry wt $\mathrm{m}^{-2} \mathrm{yr}^{-1}$. Combined annual rhizome-root production was highest at the shallowest station (234 $\mathrm{g}$ dry $w \mathrm{w} \mathrm{m}^{-2}$ ) compared to $72 \mathrm{~g}$ dry wt $\mathrm{m}^{-2}$ at deeper stations. Annual total net primary production based on the $\mathrm{O}_{2}$-method yielded the lowest results, but the seasonal pattern correlated well with results from the marking technique. Each of the 3 methods, when applied conscientiously according to the desired information, can provide reasonable estimates for the production of $C$. nodosa, although the $\mathrm{O}_{2}$-technique possibly underestimates production peaks. In order to estimate production yields only, the leaf scar method is recommended as an easily applicable technique. If production rate is one of the parameters of interest, the marking technique appears the most reliable. Average total net primary production was calculated to be ca $620 \mathrm{~g} \mathrm{dry} \mathrm{wt} \mathrm{m} \mathrm{m}^{-2} \mathrm{yr}^{-1}$ for $C$. nodosa for this part of the Adriatic Sea. Turnover rates of maximum total plant material and of only leaf material were 1.1 and $3 \mathrm{yr}^{-1}$ respectively.
\end{abstract}

\section{INTRODUCTION}

Cymodocea nodosa (Ucria) Ascherson is among the most common and abundant seagrass species in the Mediterranean Sea and along the northern parts of the Atlantic coast of Africa (Den Hartog 1970). Along the French coast of the Mediterranean this species occupies wide expanses down to $18 \mathrm{~m}$ depth (Gessner \& Hammer 1960, Caye \& Meinesz 1985) and is reported to be the most frequent phanerogam in the Gulf of Trieste (Northern Adriatic Sea) (Simonetti 1973). Eutrophication in the Northern Adriatic appears to be increasing (Degobbis et al. 1979, Stachowitsch 1986, Benovic et al. 1987, Justic 1988) and there is some evidence that the distribution of $C$. nodosa can be influenced by pollution (Avcin et al. 1974).

Surprisingly, at present almost no reliable informa- tion exists on the magnitude of primary production of this widely distributed macrophyte species. A very crude estimate of the productivity was given by Gessner \& Hammer (1960) from a mixed Caulerpa-Cymodocea stand in France; Caye \& Meinesz (1985) reported some observations on the vegetative development of the rhizome axes, but quantitative data on annual production are still lacking.

Seagrass beds are among the most productive macrophyte stands in the world with maximum productivity assessments of $>10 \mathrm{~g} \mathrm{C} \mathrm{m}^{-2} \mathrm{~d}^{-1}$ (Stevenson 1988). Nevertheless there is a long-standing debate concerning which technique for measuring primary production in seagrasses is reliable enough to make accurate estimates (for an overview see Zieman \& Wetzel 1980, Stevenson 1988). Therefore it was asked which method would provide a good compromise between ease of 
application and accuracy. Although the commonly used techniques for assessing macrophyte production have been described per se (Petersen 1918, Conover 1968, Jones 1968, Vollenweider 1969, Patriquin 1973, McRoy 1974, Zieman 1974, Sand-Jensen 1975, Svoboda \& Ott 1983, Hamburg \& Homann 1986), direct comparisons between them (i.e. same sites and species) are scarce (Bittaker \& Iverson 1976, Kemp et al. 1986, 1987, Lipkin et al. 1986) or - in the case of most seagrasses - have never been conducted.

Morphological descriptions of Cymodocea nodosa are given in detail by Bornet (1864) and Tomlinson (1974). A clear morphological differentiation of the axes, relating to the seasonality of its growth, reflects a more or less dormant stage in winter when most leaves are lost. The consistent seasonal sequence of long and short internodes at both vertical and horizontal types of axes allows determination of annual growth increments (Tomlinson 1974, Caye \& Meinesz 1985, Pirc unpubl.). Leaf development was also described as being subject to a seasonal growth thythm (Caye \& Meinesz 1985).

In the present study a method based on changes in biomass is adapted; it takes advantage of the abovementioned morphological differentiations and the presence of leaf scars (Brouns 1985, Pirc unpubl.) as an indication of the number of torn off and exported leaf blades.

The reliability of this method was tested by a comparison with 2 established approaches during an annual cycle: a marking technique and the determination of oxygen production in situ. The latter method was preferred over carbon incorporation techniques, which were found to seriously underestimate productivity in many macrophytes (Iipkin et al. 1986, Stevenson 1988). Since the previously reported drawback of oxygen measurements due to lacunal gas storage (Hartman \& Brown 1967, Zieman \& Wetzel 1980) is not supported by several authors (Nixon \& Oviatt 1972, Roberts \& Moriarty 1987, Stevenson 1988), this technique was included in our comparison of methods.

The aim of this study was 2-fold: to compare the reliability of 3 methods for assessing primary production and to provide an estimate of annual production of Cynodocea nodosa in the Northern Adriatic Sea.

\section{MATERIAL AND METHODS}

Study area. All sampling and in situ measurements were conducted in the Bay of Piran, which is located in the Gulf of Trieste in the Northern Adriatic Sea (Fig. 1). Three permanent stations were established along a transect in the back area of the bay, where Cymodocea nodosa grows in dense stands between depths of 0.5 and $7 \mathrm{~m}$. Stns R1 $(2 \mathrm{~m}), \mathrm{R} 2(4 \mathrm{~m})$ and R3 $(6 \mathrm{~m})$ were

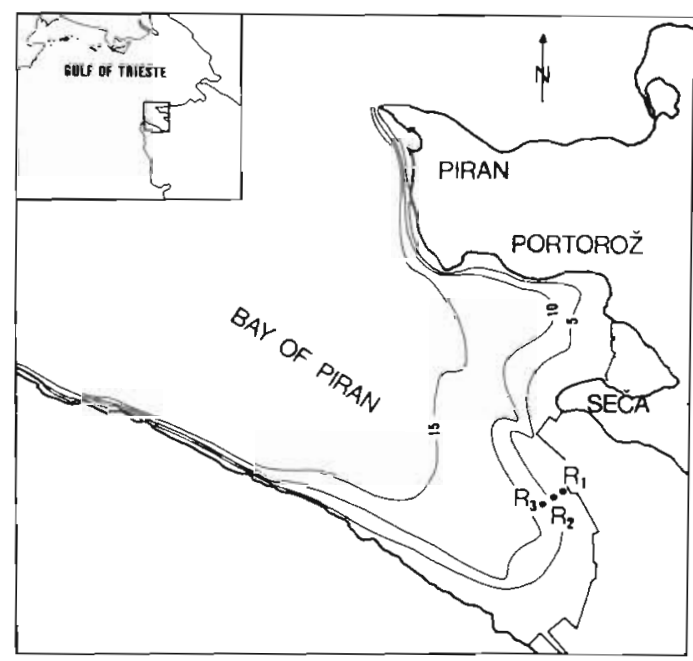

Fig. 1. Study area, sampling and experimental positions

marked with concrete blocks and were considered to be representative for conditions within the whole area. The sediment consists largely of silt and clay (Ranke 1976), frequently resulting in reduced water transparency due to resuspension of material (Herndl \& Peduzzi 1988). Therefore the depth distribution of the seagrass appears to be limited compared to other locations (Caye \& Meinesz 1985).

Sampling and biomass. Sampling was conducted about every 2 mo from April 1987 to March 1988 using SCUBA. At each station (R1, R2, R3) 3 cores were extracted randomly from the meadow with a thin-wall, serrated, stainless steel core tube $(18.5 \mathrm{~cm}$ diameter $)$ inserted to a depth of $30 \mathrm{~cm}$ (i.e. maximum root length). All plant material was washed with seawater in a 1.5 $\mathrm{mm}$ mesh sieve to remove sediments and temporarily stored in labeled plastic bags in a refrigerator $\left(<6^{\circ} \mathrm{C}\right)$ until processing. For biomass determination, leaves, rhizomes and roots were separated and rinsed with tap water to remove the salts. Live roots and rhizomes were separated from dead macro-organic matter which was excluded from all determinations. Throughout most of the study period the leaves were not subjected to severe epiphytism and occasional epigrowth could easily be removed with fingernails when necessary (Kemp et al. 1987). The material was dried at $75^{\circ} \mathrm{C}$ to constant weight to determine the dry weight of each fraction. Subsamples of all fractions were analyzed for $\mathrm{C}$ - and $\mathrm{N}$-content in a Carlo Erba ANA-1500-C/H/Nanalyzer.

The frequency of shoots as well as the number of leaves within each shoot were determined in each sample. Leaf length was measured to the nearest 0.1 $\mathrm{cm}$, leaf width to the nearest $0.1 \mathrm{~mm}$.

Primary production. All primary production estimates are based on vegetative growth only, since in 
the course of this study sexual production was never detected in the investigated area.

Leaf scar method. Production is defined as the build up of new organic matter plus any losses over a period of time (Zieman \& Wetzel 1980). Therefore, the measurement of peak standing biomass without supportive information on the loss of dead plant material underestimates true net production (Hackney \& Hackney 1978, Hopkinson et al. 1978, Schubauer \& Hopkinson 1984). Most seagrasses export their leaves more or less continuously over the entire growing season (Ott 1980, Zieman \& Wetzel 1980). Reliable production estimates require that the loss of this material be accounted for.

We used a method based on standing biomass observations as well as on the export rate of leaves, indicated by leaf scars on the shoots. Losses as sloughed leaves were estimated from the mean number of leaf scars appearing during the growing season per shoot. From the core samples, taken bimonthly for biomass determinations, 20 to 146 shoots were subsampled randomly; numbers of both leaf scars and attached live leaves were counted. The length and dry weight of the longest leaf on a shoot were determined on each sampling date. The sample material revealed that less than $5 \%$ of the longest leaves had tissue broken off at the tips; this indicates that these were the youngest leaves in which elongation can be assumed to have ceased. Therefore the longest leaf was taken to be representative in size of the recently lost leaves (see also Kentula \& Mclntire 1986).

Loss of material was calculated cumulatively as the mean number of leaves lost per shoot since the last sampling date multiplied by the mean dry weight of the longest leaf in the respective season. Annual leaf production was then estimated as the difference between the minimum standing biomass at the beginning of the growing season (April) and the maximum total biomass of leaf material (i.e. the sum of maximum standing crop plus all hitherto exported leaf material) in September.

Marking method. From October 1987 to September 1988, between 11 and 31 whole leaf bundles of individual shoots (i.e. all leaf bundles within a defined area of $225 \mathrm{~cm}^{-2}$ ) were punched with a needle at each of the 3 stations at 2 mo intervals. The holes were punched ca 1 to $2 \mathrm{~cm}$ above the meristematic zones. Due to the constancy of length of older leaves (Hamburg \& Homann 1986; and confirmed for Cymodocea nodosa in this study) the hole in the outermost, oldest leaf can be used as a reference level. Several $\mathrm{cm}$ above the first hole a second hole was punched only in the reference leaf of each bundle for the later identification of this oldest leaf. This modification of the Zieman (1974) marking technique substantially simplifies the field work. After 7 to $20 \mathrm{~d}$ (depending on the season) the shoots were harvested and the segments of new growth removed (including newly appeared leaves), rinsed, dried $\left(75^{\circ} \mathrm{C}\right)$ and weighed. Bundles without a clearly identifiable reference leaf were excluded from the measurements.

Seasonal leaf net production ( $g$ dry $w t \mathrm{~m}^{-2}$ ) was calculated as the mean leaf production per shoot times the mean shoot density of the respective season.

Rhizome and root production. Rhizome and root production was estimated from the material sampled at the 3 stations with the corer. As stated earlier, the yearly onset of new rhizome growth can be determined easily on rhizome samples (Tomlinson 1974, Caye \& Meinesz 1985, Pirc pers. comm.). Therefore rhizome growth was determined by cutting off the 1987 production increment in the late autumn samples when rhizome growth was found to have ceased. A total of 425 live rhizome pieces were separated from the advantitious roots and dried to constant weight $\left(75^{\circ} \mathrm{C}\right)$.

Root production was calculated as the difference between the maximum and minimum mass of live root material observed over a 1 yr period (de la Cruz \& Hackney 1977, Gallagher \& Plumley 1979, Smith et al. 1979, Hackney \& de la Cruz 1986).

Oxygen method. At Stn R2, oxygen metabolism of Cymodocea nodosa was measured in situ by the change in $\mathrm{O}_{2}$ concentration in a closed system at ca 2 mo intervals between October 1987 and September 1988 (in total 28 experimental runs). A battery-driven multichannel UW-respiration set - equipped with polarographic oxygen sensors of the Clark type (YSI) continuously monitored the $\mathrm{O}_{2}$ concentration within transparent acrylic chambers. Jars of various sizes (2 to 7.8 1) were used depending on seasonal differences in leaf length. This prevented the $\mathrm{O}_{2}$ concentration from deviating more than $25 \%$ from the initial concentration over a $24 \mathrm{~h}$ period (Peduzzi et al. unpubl.). The bell jars were fitted with $\mathrm{O}$-rings to short polypropylene tubes with a metal cutting edge which were driven into the sediment and rhizome layer. Two measurements can be conducted simultaneously. This set up is described in detail by Svoboda \& Ott (1983) and was also successfully used in studies on benthic community metabolism within the Bay of Piran (Herndl et al. 1989, Peduzzi et al. unpubl.).

Following an incubation period of ca 24 h the chambers were lifted carefully from the basal rings by gently blowing air into the jars. All photosynthetic (i.e. green) leaf tissue was clipped off with scissors and placed in plastic bags for later dry weight determination. The incubation area was sealed again with a small jar (2 l) and the benthic metabolism (i.e. production and consumption of $\mathrm{O}_{2}$ by the sediment community, including microautotrophic and heterotrophic organisms; see Murray \& Wetzel 1987) was continuously recorded over another $24 \mathrm{~h}$ period. 
Water column metabolism was estimated by $\mathrm{O}_{2}$ changes in clear and dark jars $(900 \mathrm{ml}$ ) filled with ambient water and positioned within the meadow, 15 $\mathrm{cm}$ above the sediment surface, Little epiphytic growth was visible on experimental seagrass leaves, and epiphyte $\mathrm{O}_{2}$ metabolism, per se, was therefore not considered. Nevertheless, in late summer incubations the modest epigrowth was removed carefully prior to measurements. $\mathrm{O}_{2}$ metabolism of Cymodocea nodosa (and its few remaining epiphytes) was calculated from hourly changes in $\mathrm{O}_{2}$ concentrations within the total community, corrected for the sediment and planktonic production and consumption rates.

Estimates of annual production rates were evaluated as described by Murray \& Wetzel (1987).

All measurements with the oxygen method were performed under insolation conditions which were assumed to be representative for the respective season. This was confirmed by simultaneously conducted light measurements (PAR 400 to $700 \mathrm{~nm}_{i}$ ranging from $1.5 \mathrm{E}$ $\mathrm{m}^{-2} \mathrm{~d}^{-1}$ in winter to $11.5 \mathrm{E} \mathrm{m}^{-2} \mathrm{~d}^{-1}$ in summer) which will be presented elsewhere together with a more detailed description of the entire experimental procedure (Peduzzi et al. unpubl.; see also Kemp et al. 1987 , Murray \& Wetzel 1987).

For comparison with the results of net primary production (NPP) measurements obtained from the other techniques outlined above, the oxygen data were converted to carbon equivalents using a factor of $0.31 \times$ $\mathrm{mg} \mathrm{C}=\mathrm{mg} \mathrm{O} \mathrm{O}_{2}$ (McRoy \& McMillan 1977).

During each experimental run, temperature was recorded from sensors contained in the $\mathrm{O}_{2}$-probes.

\section{RESULTS}

\section{Temperature regime}

Highest water temperatures were recorded between the end of June and the end of August with maximum values of $24.5^{\circ} \mathrm{C}$ (Fig. 2). The minimum temperature was observed in March $\left(9.4^{\circ} \mathrm{C}\right)$.

\section{Biomass}

Biomass of total (above- and belowground) material of Cymodocea nodosa exhibited seasonal patterns at all 3 stations (Fig. 3). The standing crop began to increase at the shallow station $(\mathrm{R} 1 ; 2 \mathrm{~m}$ ) in March, at Stn R2 (4 $\mathrm{m})$ and $\mathrm{R} 3(6 \mathrm{~m})$ in April, reaching a maximum in August through September at all stations. Mean maximum total biomass expressed as dry weight was 1020 $\mathrm{g} \mathrm{m}^{-2}$ at $\mathrm{Stn} \mathrm{R} 1,323 \mathrm{~g} \mathrm{~m}^{-2}$ at Stn R2 and $341 \mathrm{~g} \mathrm{~m}^{-2}$ at Stn R3. Minimum standing crop was observed in early

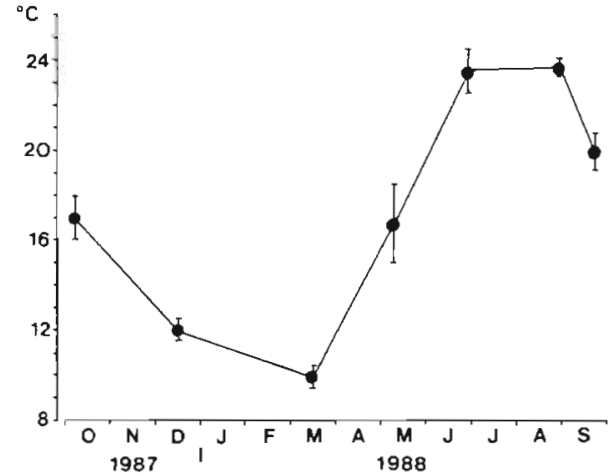

Fig. 2. Temperature regime at $4 \mathrm{~m}$ depth (Stn R2) from October 1987 to September 1988

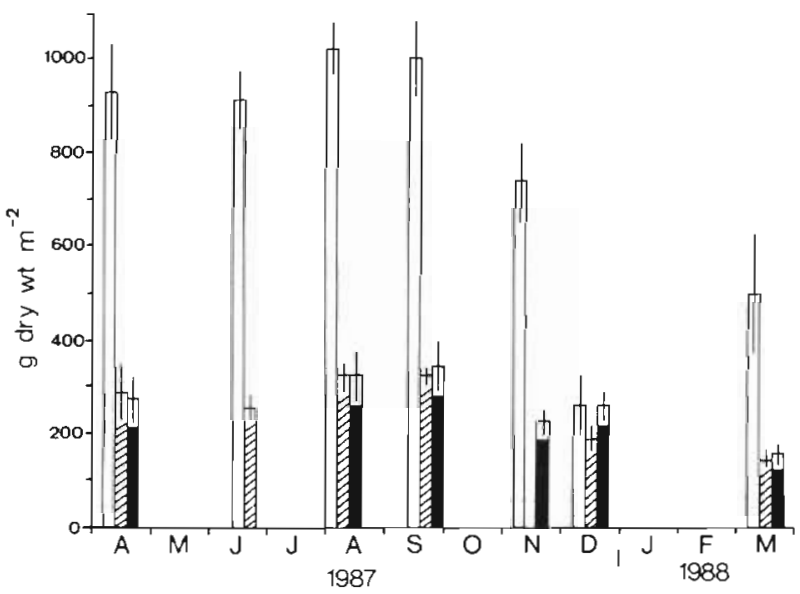

Fig. 3. Cymodocea nodosa. Total biomass at Str R1 (open bars), R2 (hatched bars) and R3 (solid bars) during the period from April 1987 to March 1988. Each value represents the mean of 3 observations; vertical lines indicate $\pm 1 \mathrm{SE}$

winter at Stn R1, whereas the deeper Stns R2 and R3 exhibited their minimum biomass in March. On an annual basis the standing crop at Stn R1 was ca 3 times the biomass of the deeper Stns R2 and R3.

At all stations, belowground biomass (i.e. rhizome and root material) was a greater proportion of the total biomass than aboveground biomass throughout the whole year (Table 1). The only exception was Stn R3 in August, where aboveground biomass approximately equaled belowground biomass. The belowground: aboveground biomass ratios were highest at Stn $\mathrm{R} 1$ and varied throughout the growing season between 3.3 (August) and a maximum value of 12.3 (April). In contrast the ratios at the deeper stations were always much lower, varying between 0.9 (August) and 5.5 (April). On an annual basis the high total biomass at the shallow station was largely comprised of belowground plant material, with an average of $87.6 \%$ compared to $60.7 \%$ for the deeper stations. 
Table 1. Cynodocea nodosa. Belowground (B) : aboveground (A) biomass ratios and mean leaf area index (LAI) at the 3 stations from April 1987 to March 1988. Standard error is given in parentheses; n: no. of observed shoots for LAI determination; -: no data available

\begin{tabular}{|c|c|c|c|c|c|c|c|c|c|}
\hline \multirow[t]{2}{*}{ Month } & \multicolumn{3}{|c|}{$\operatorname{Sin} R_{1}$} & \multicolumn{3}{|c|}{ Stn R2 } & \multicolumn{3}{|c|}{ Stn R3 } \\
\hline & B:A ratio & LAI & $\mathrm{n}$ & $B: A$ ratio & LAI & $\mathrm{n}$ & B:A ratio & LAI & $\mathrm{n}$ \\
\hline \multicolumn{10}{|l|}{1987} \\
\hline Apr & 12.3 & $\begin{array}{c}0.33 \\
(0.13)\end{array}$ & 145 & 5.3 & $\begin{array}{c}0.21 \\
(0.11)\end{array}$ & 85 & 5.5 & $\begin{array}{c}0.21 \\
(0.10)\end{array}$ & 80 \\
\hline Jun & 5.5 & $\begin{array}{c}2.88 \\
(1.12)\end{array}$ & 180 & 2.0 & $\begin{array}{c}2.19 \\
(1.20)\end{array}$ & 83 & - & - & - \\
\hline Aug & 3.3 & $\begin{array}{c}7.24 \\
(3.23)\end{array}$ & 39 & 1.4 & $\begin{array}{c}5.21 \\
(2.12)\end{array}$ & 40 & 0.9 & $\begin{array}{c}3.37 \\
(1.56)\end{array}$ & 87 \\
\hline Sep/Oct & 7.8 & $\begin{array}{c}2.56 \\
(1.32)\end{array}$ & 21 & 2.5 & $\begin{array}{c}1.97 \\
(0.94)\end{array}$ & 20 & 2.1 & $\begin{array}{c}1.54 \\
(0.81)\end{array}$ & 15 \\
\hline Dec & 5.7 & $\begin{array}{c}0.24 \\
(0.13)\end{array}$ & 17 & 4.1 & $\begin{array}{c}0.32 \\
(0.16)\end{array}$ & 21 & 4.1 & $\begin{array}{c}0.16 \\
(0.09)\end{array}$ & 17 \\
\hline \multicolumn{10}{|l|}{1988} \\
\hline Mar & 11.3 & $\begin{array}{c}0.21 \\
(0.15)\end{array}$ & 22 & 5.4 & $\begin{array}{c}0.16 \\
(0.09)\end{array}$ & 20 & 5.3 & $\begin{array}{c}0.12 \\
(0.07)\end{array}$ & 19 \\
\hline
\end{tabular}

During spring and early summer, leaf morphology changed at all stations from the small, narrow leaves typical of late autumn and winter to the long, wide leaves found during summer. Leaf width usually varied throughout the year between 1.5 and $4 \mathrm{~mm}$; maximum leaf lengths of more than $60 \mathrm{~cm}$ were observed in August at Stn R1 (Fig. 4A). The average dry weight of the longest leaves roughly followed the pattern of changing length throughout the growing season, although seasonal differences were less pronounced (Fig. 4A, B).

At all 3 stations the leaf area index (LAI; i.e. length $x$ width $\times \mathrm{m}^{-2}$ ) reached maximum values in August; minimum values were observed in March (Table 1).

Since no significant differences in $\mathrm{C}$ - and $\mathrm{N}$-content were found between the 3 stations ( $t$-test, in all cases $p$ $>0.5$ ), the data were pooled. C- and N-concentrations in all fractions of live plant material (leaves, rhizomes, roots) are given in Table 2 . Whereas C-content was quite similar in all plant organs, $\mathrm{N}$-content was clearly highest in leaf material.

During the sampling period, shoot density followed the same general patterns of change at Stns R2 and R3, with the minimum density in early spring; at Stn R1 the minimum value was observed in winter. Maximum shoot densities were reached in August at all 3 stations (Table 3).

\section{Net production}

Information concerning the dry weight of the largest leaves and the abundance of both live leaves and leaf scars per shoot was synthesized in order to estimate export rates and NPP of Cymodocea nodosa leaf
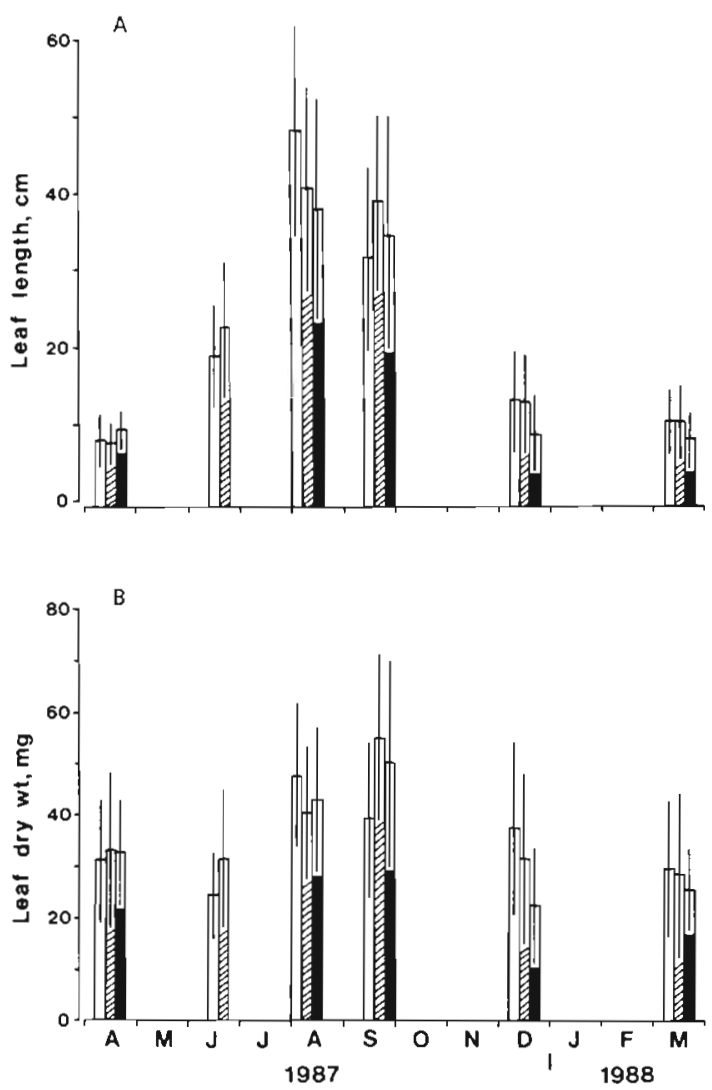

Fig. 4. Cymodocea nodosa. Seasonal pattern of (A) length and (B) dry weight of the largest leaf on shoots. Open bars: Stn R1; hatched bars: Stn R2; solid bars: Stn R3; vertical lines indicate $\pm 1 \mathrm{SE}$

material (Table 4). Biomass accumulation from leaf standing crop (LSC) and losses associated with sloughed leaves are presented in Fig. 5. The maximum 
Table 2. Cynodocea nodosa. Mean carbon and nitrogen content in plant material. Standard error is given in parentheses; $\mathrm{n}$ : no. of determinations

\begin{tabular}{|lccc|}
\hline & Leaves & Rhizomes & Roots \\
\hline $\mathrm{n}$ & 31 & 37 & 35 \\
C, \% of dry wt & 46.87 & 47.22 & 47.84 \\
& $(1.86)$ & $(3.42)$ & $(1.77)$ \\
N, \% of dry wt & 2.75 & 1.06 & 1.84 \\
& $(0.31)$ & $(0.14)$ & $(0.29)$ \\
\hline
\end{tabular}

Table 3. Cynodocea nodosa. Mean shoot density at 3 stations from April 1987 to March 1988. Values represent no. of shoots $\mathrm{m}^{-2}$ as determined by 3 replicate core samples at each month and each station. Standard error is given in parentheses; -; no data available

\begin{tabular}{|crrr|}
\hline Month & Stn R1 & Stn R2 & Stn R3 \\
\hline $\mathbf{1 9 8 7}$ & & & \\
Apr & 1835.2 & 1066.5 & 992.1 \\
& $(85.9)$ & $(381.8)$ & $(183.5)$ \\
Jun & 2318.8 & 1202.7 & - \\
& $(485.5)$ & $(568.5)$ & \\
Aug & 2612.7 & 2157.7 & 1760.8 \\
& $(251.5)$ & $(111.6)$ & $(527.9)$ \\
Sep/Oct & 1822.9 & 942.3 & 1116.1 \\
& $(428.9)$ & $(171.9)$ & $(572.5)$ \\
Dec & 681.9 & 967.3 & 930.1 \\
& $(325.2)$ & $(242.2)$ & $(223.2)$ \\
$\mathbf{1 9 8 8}$ & & & \\
Mar & 1153.3 & 545.8 & 512.1 \\
& $(297.6)$ & $(85.9)$ & $(69.3)$ \\
\hline
\end{tabular}

cumulative leaf biomass - as the sum of LSC and estimated exported leaf material - was observed by the end of September at all 3 stations. Export rates were highest in summer; this coincides with maximum LSC thus indicating the high leaf productivity during this period.

At Stn R1, maximum numbers of 4 to 5 live leaves per shoot were rarely observed; more commonly, 2 to 3 leaves could be counted per shoot in summer. At Stns R2 and R3, leaf abundance was even lower. The mean total number of leaves produced per shoot per year, as determined from the late winter samples, was 9.74 ( $\mathrm{n}=$ $22, \mathrm{SE}=2.71)$ at $\mathrm{Stn} \mathrm{R} 1,9.70(\mathrm{n}=20, \mathrm{SE}=2.82)$ at $\mathrm{Stn}$ $\mathrm{R} 2$ and $9.61(\mathrm{n}=25, \mathrm{SE}=2.54)$ at $\mathrm{Stn} \mathrm{R} 3$.

Based on the leaf scar method, annual leaf NPP was calculated as $691.7 \mathrm{~g}$ dry wt $\mathrm{m}^{-2}$ at $\mathrm{Stn} \mathrm{R} 1,473.4 \mathrm{~g}$ dry wt $\mathrm{m}^{-2}$ at Stn R2 and $547.6 \mathrm{~g}$ dry wt $\mathrm{m}^{-2}$ at Stn R3

Leaf net productivity per shoot as measured by the marking technique was very similar comparing the 3 stations throughout the growing season (t-test, in all cases $p \geq 0.1$ ) with one exception in September 1988 . when productivity was significantly lower $(p<0.01)$ at Stn R2. Fig. 6 presents the daily average areal $\left(\right.$ per $\mathrm{m}^{2}$ ) leaf net production for each season, based on the respective shoot densities, for all 3 stations. In winter no measurable leaf growth could be detected with the marking technique. After peak production in early and mid-summer, with maximum leaf elongations of up to 18 $\mathrm{cm} \mathrm{wk}^{-1}$ (as observed in July 1988 at Stn R1), production rates dropped drastically by the end of summer.

Integrating seasonal production rates obtained by the marking method over the entire growing season resulted in an annual leaf NPP estimate of $716.7 \mathrm{~g}$ dry

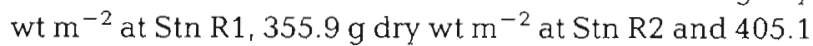
g dry wt $\mathrm{m}^{-2}$ at $\mathrm{Stn}$ R3.

The annual increment of rhizome axes was almost equal (t-test, $p>0.2$ ) for Stns R2 and R3, whereas at Stn R1 rhizome growth was somewhat higher $(p>0.1$; Table 5)

Based on the average areal rhizome abundance between April and September 1987, we estimated rhizome production to be $62.5 \mathrm{~g}$ dry wt $\mathrm{m}^{-2} \mathrm{yr}^{-1}$ at Stn $\mathrm{R} 1,33.6 \mathrm{~g}$ dry wt $\mathrm{m}^{-2} \mathrm{yr}^{-1}$ at Stn R2 and $34.2 \mathrm{~g}$ dry wt $\mathrm{m}^{-2} \mathrm{Yr}^{-1}$ at $\mathrm{Stn} \mathrm{R} 3$.

Root production estimates were more than 4 times higher at Stn R1 (171.7 g dry wt $\mathrm{m}^{-2} \mathrm{yr}^{-1}$ ) than at Stn R2 ( $36.8 \mathrm{~g} \mathrm{dry} \mathrm{wt} \mathrm{m}^{-2} \mathrm{yr}^{-1}$ ). No distinct seasonal pattern of root biomass could be detected at Stn R3; root production was therefore not calculated for this location.

NPP estimates for Cymodocea nodosa at Stn R2, based on the $\mathrm{O}_{2}$-method, are summarized in Table 6 . Conversions to dry weight were calculated using the Ccontent values in Table 2, and the areal NPP is based on the LSC of the respective season. Net productivity increased continuously during spring and reached a distinct maximum in mid-summer. Using this method, net productivity was observed even during winter, although it yielded very low values of areal NPP.

Annual total NPP, as determined by the $\mathrm{O}_{2}$-method by integrating seasonal productivity values over the $1 \mathrm{yr}$ investigation period, yielded $379.1 \mathrm{~g} \mathrm{dry} \mathrm{wt} \mathrm{m}^{-2}$ at Stn R2.

\section{DISCUSSION}

\section{Biomass}

Changes in the total biomass and shoot density of Cymodocea nodosa in the Bay of Piran throughout the year exhibited a pattern comparable to other seagrasses of temperate regions (McRoy \& McMillan 1977. Zieman \& Wetzel 1980, Kentula \& McIntire 1986). A clear seasonality has been reported for $C$. nodosa (Simonett. 1973, Tomlinson 1974, Caye \& Meinesz 1985, Pirc \& Wollenweber 1988), and our results also strongly suggest a dependence on the changing tem- 
Table 4. Cynodocea nodosa. Number of attached leaves and leaf scars per shoot at 3 stations (R1, R2, R3) from April 1987 to March 1988. Leaf export rates are calculated values for periods equal to sampling intervals. Standard errors are given in parentheses; $n$ : no. of investigated shoots; -: no data available

\begin{tabular}{|c|c|c|c|c|c|c|}
\hline \multirow[t]{2}{*}{ Month } & \multirow[t]{2}{*}{$\mathrm{n}$} & \multirow{2}{*}{$\begin{array}{l}\text { Attached live } \\
\text { leaves shoot }\end{array}$} & \multirow{2}{*}{ Leaf scars shoot ${ }^{-1}$} & \multirow{2}{*}{$\begin{array}{c}\text { New leaf scars } \\
\text { shoot }^{-1 a}\end{array}$} & \multicolumn{2}{|c|}{ Leaf export rate } \\
\hline & & & & & $\begin{array}{l}\operatorname{mg} d r y w t \\
\text { shoot }^{-1 a}\end{array}$ & $\underset{m^{-2 a}}{\operatorname{gdry} w t}$ \\
\hline \multicolumn{7}{|l|}{ Stn R1 } \\
\hline Apr & 146 & $\begin{array}{c}1.24 \\
(0.43)\end{array}$ & 0 & 0 & 0 & 0 \\
\hline Jun & 126 & $\begin{array}{c}2.81 \\
(0.90)\end{array}$ & $\begin{array}{c}1.80 \\
(0.61)\end{array}$ & 1.80 & 43.5 & 100.9 \\
\hline Aug & 39 & $\begin{array}{c}2.36 \\
(0.74)\end{array}$ & $\begin{array}{c}4.81 \\
(1.12)\end{array}$ & 3.01 & 143.9 & 376.1 \\
\hline Sep/Oct & 21 & $\begin{array}{c}1.86 \\
(0.57)\end{array}$ & $\begin{array}{c}7.20 \\
(1.88)\end{array}$ & 2.39 & 94.0 & 174.4 \\
\hline Dec & 20 & $\begin{array}{c}1.18 \\
(0.33)\end{array}$ & $\begin{array}{c}8.50 \\
(2.34)\end{array}$ & 1.30 & 49.0 & 33.4 \\
\hline Mar & 22 & $\begin{array}{c}1.14 \\
(0.35)\end{array}$ & $\begin{array}{c}8.60 \\
(2.71)\end{array}$ & 0.10 & 2.9 & 3.4 \\
\hline \multicolumn{7}{|l|}{ Stn $\mathrm{R} 2$} \\
\hline Apr & 66 & $\begin{array}{c}1.36 \\
(0.48)\end{array}$ & 0 & 0 & 0 & 0 \\
\hline Jun & 96 & $\begin{array}{c}2.84 \\
(1.20)\end{array}$ & $\begin{array}{c}1.84 \\
(0.58)\end{array}$ & 1.84 & 57.7 & 69.5 \\
\hline Aug & 40 & $\begin{array}{c}2.25 \\
(1.10)\end{array}$ & $\begin{array}{c}4.70 \\
(1.18)\end{array}$ & 2.86 & 115.1 & 248.4 \\
\hline Sep/Oct & 20 & $\begin{array}{l}2.15 \\
(0.75)\end{array}$ & $\begin{array}{c}6.80 \\
(1.72)\end{array}$ & 2.10 & 115.6 & 108.9 \\
\hline Dec & 20 & $\begin{array}{c}1.25 \\
(0.44)\end{array}$ & $\begin{array}{c}8.30 \\
(2.15)\end{array}$ & 1.50 & 46.9 & 45.4 \\
\hline Mar & 20 & $\begin{array}{c}1.30 \\
(0.47)\end{array}$ & $\begin{array}{c}8.40 \\
(2.79)\end{array}$ & 0.10 & 2.8 & 1.6 \\
\hline \multicolumn{7}{|l|}{ Stn R3 } \\
\hline Apr & 55 & $\begin{array}{c}1.35 \\
(0.55)\end{array}$ & 0 & 0 & 0 & 0 \\
\hline Jun & - & - & - & - & - & - \\
\hline Aug & 87 & $\begin{array}{l}1.87 \\
(0.85)\end{array}$ & $\begin{array}{c}4.82 \\
(1.25)\end{array}$ & 4.82 & 208.9 & 367.7 \\
\hline $\mathrm{Sep} / \mathrm{Oct}$ & 20 & $\begin{array}{c}1.80 \\
(0.56)\end{array}$ & $\begin{array}{c}6.81 \\
(1.83)\end{array}$ & 1.99 & 100.3 & 111.9 \\
\hline Dec & 27 & $\begin{array}{c}1.20 \\
(0.37)\end{array}$ & $\begin{array}{c}8.37 \\
(2.27)\end{array}$ & 1.56 & 34.4 & 32.0 \\
\hline Mar & 25 & $\begin{array}{c}1.21 \\
(0.31)\end{array}$ & $\begin{array}{c}8.40 \\
(2.51)\end{array}$ & 0.03 & 0.8 & 0.4 \\
\hline
\end{tabular}

perature and light regime (compare Figs. 2 and 3). The highest shoot density in summer at Stn R1 is well above values reported for C. nodosa elsewhere (Caye \& Meinesz 1985, Pirc unpubl.) although such high values can also be expected for other locations as indicated in the study of Gessner \& Hammer (1960), who reported close to 9000 leaves $\mathrm{m}^{-2}$ in early October along the French coast. In the study area the reduced water transparency mentioned above seems to influence shoot density along the depth gradient.

Peak biomass at Stn R1 is close to values reported for several tropical seagrasses, whereas Stns R2 and R3 exhibit a maximal standing crop more similar to the temperate species Zostera marina (compare Stevenson 1988). The minimum biomass in early winter at Stn R1 compared to the much later minimum at the deeper stations could be interpreted as the effect of stronger wave action at the shallow location due to heavy winds in late autumn

At Stn R1, the overall high belowground:aboveground biomass ratio and the relatively high root production rate may be the result of more severe physical 

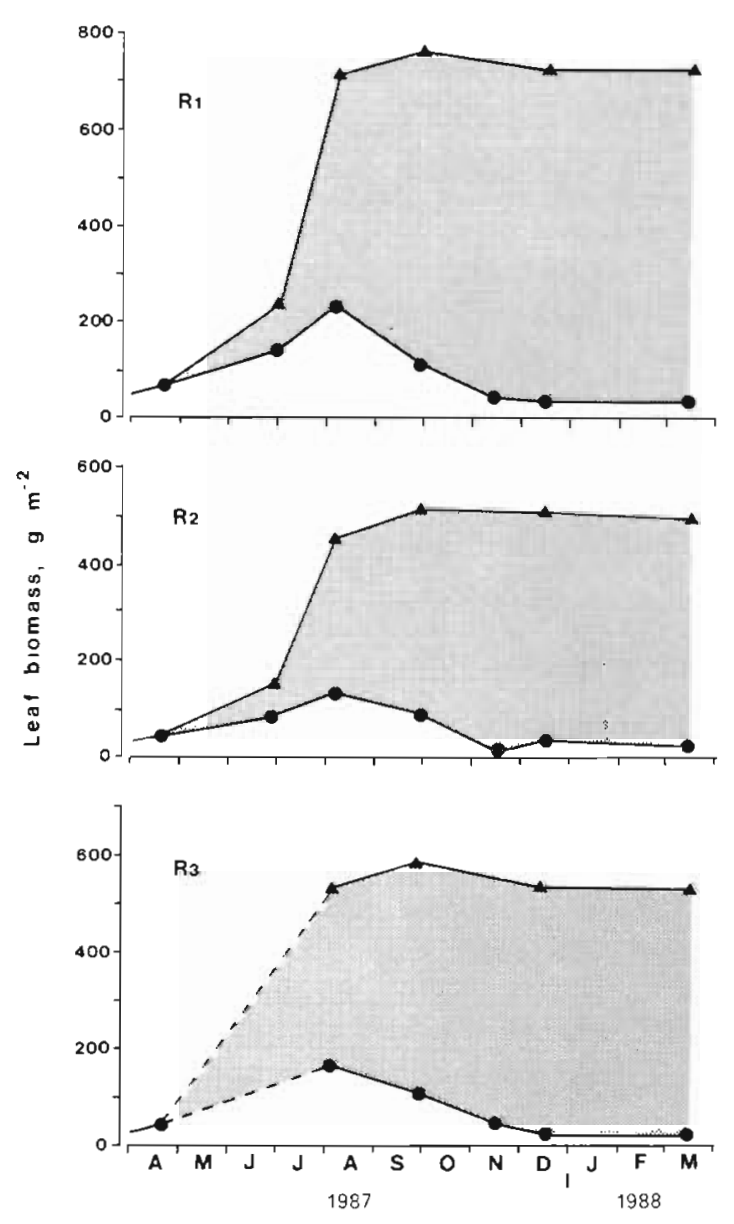

Fig 5. Cymodocea nodosa. Biomass accumulation in g dry wt of leaf matenal during one production period at 3 stations ( $R 1$, R2, R3). ( $\bullet$ Development of leaf standing crop. ( 4 ) total produced leaf matenal cumulatively; stippled area represents exported leaf matenal as sloughed leaves. At Stn R3 no data are avallable for late June, a dashed lne was drawn, although a configuration similar to R1 and R2 can be expected

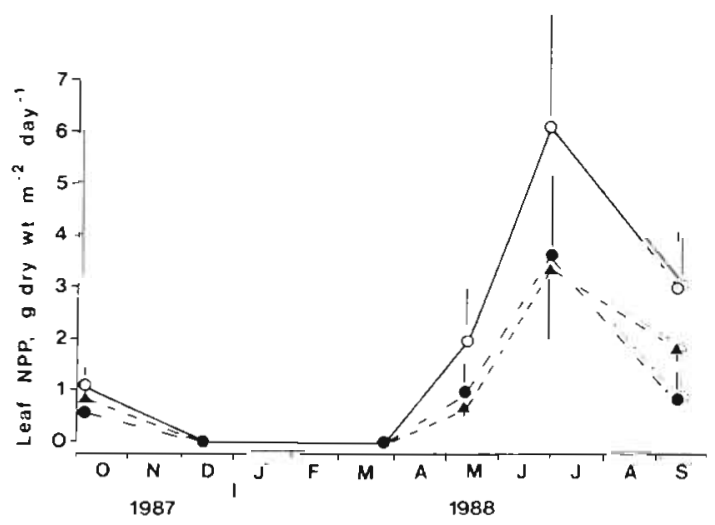

Fig 6 Net primary production of leaves as obtained by the markıng technique at the 3 stations R1 ( ), R2 (•) and R3 (4) SE 15 indicated by vertical lines, to one side only (Stns R1 and R2 up: Stn R3: down, no line SE smaller than symbols)
Table 5. Cynodocea nodosa. Rhizome increment of the 1987 production penod. $\overline{\mathrm{x}}$ mean value; SE: standard error; $\mathrm{n}$ : no. of investigated rhizome axes

\begin{tabular}{|llll|}
\hline & $\begin{array}{c}\text { Rhizome production, } \\
\text { Stn R1 }\end{array}$ & Stn R2 & \multicolumn{1}{c|}{$\begin{array}{c}\text { Stn R3 } \\
\text { Str }\end{array}$} \\
\hline$\widetilde{X}$ & 2908 & 25.04 & 26.55 \\
SE & 1194 & 13.57 & 11.75 \\
$\mathrm{n}$ & 151 & 133 & 141 \\
\hline
\end{tabular}

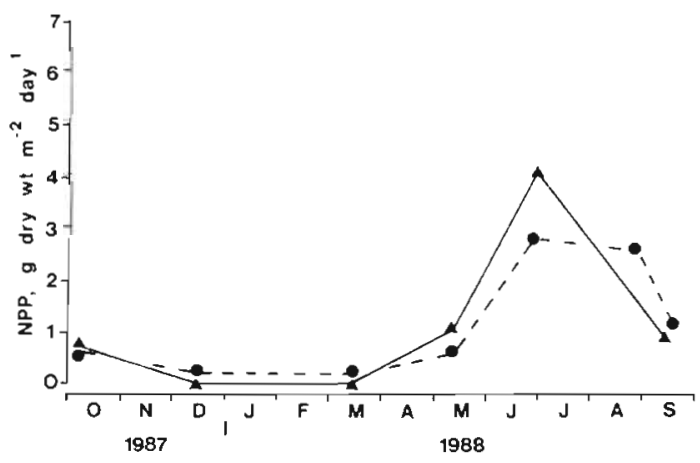

Fig. 7. Cymodocea nodosa. Seasonal pattern of net primary production obtained by the marking technique ( $\mathbf{\Delta}$ ) and the

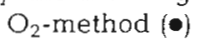

Table 6 Cynodocea nodosa. Net productivity and areal net production as measured by the $\mathrm{O}_{2}$-method at $\mathrm{Stn}$ R2. Values represent the mean of 4 replicate measurements; standard errors are given in parentheses. For further details see text

\begin{tabular}{|c|c|c|c|}
\hline \multirow[t]{2}{*}{ Month } & \multicolumn{2}{|c|}{ Net productivity } & \multirow{2}{*}{$\begin{array}{c}\text { Areal net } \\
\text { production } \\
g \text { dry wt } \\
\mathrm{m}^{-2} \mathrm{~d}^{-1}\end{array}$} \\
\hline & $\begin{array}{c}\operatorname{mg} \mathrm{Cg}^{-1} \\
\text { (leaf dry } w t) \\
d^{-1}\end{array}$ & $\begin{array}{c}\text { mg dry wt } g^{-1} \\
\text { (leaf dry wt) } \\
d^{-1}\end{array}$ & \\
\hline \multicolumn{4}{|l|}{1987} \\
\hline Oct & $\begin{array}{c}363 \\
(105)\end{array}$ & 7.74 & 0.697 \\
\hline Dec & $\begin{array}{c}270 \\
(087)\end{array}$ & 5.76 & 0.212 \\
\hline \multicolumn{4}{|l|}{1988} \\
\hline Mar & $\begin{array}{c}4.38 \\
(055)\end{array}$ & 9.34 & 0.209 \\
\hline May & $\begin{array}{c}562 \\
(004)\end{array}$ & 11.99 & 0.600 \\
\hline Jun & $\begin{array}{l}1561 \\
(453)\end{array}$ & 33.30 & 2.832 \\
\hline Aug & $\begin{array}{c}956 \\
(169)\end{array}$ & 20.40 & 2.611 \\
\hline Sep & $\begin{array}{c}528 \\
(0.75)\end{array}$ & 11.27 & 1.183 \\
\hline
\end{tabular}


Table 7. Cynodocea nodosa. Annual total net primary production (NPP) obtained by 3 different methods ( $\mathrm{g}$ dry wt $\mathrm{m}^{-2}$ )

\begin{tabular}{|lccc|}
\hline Station & $\begin{array}{c}\text { Leaf scar } \\
\text { method }\end{array}$ & $\begin{array}{c}\text { Marking } \\
\text { method }\end{array}$ & $\mathrm{O}_{2}$-method \\
\hline R1 & 925.9 & 950.9 & - \\
R2 & 545.8 & 428.3 & 379.1 \\
R3 & $581.8^{\mathrm{d}}$ & $439.3^{\mathrm{a}}$ & - \\
& & \\
\hline
\end{tabular}

forces such as waves in this shallow area. Although at Stns R2 and R3 the ratios were somewhat lower, they were in general $>1$ which is typical for seagrass species (Stevenson 1988) and plants growing under harsh environmental conditions (Schubauer \& Hopkinson 1984). Increased belowground biomass may help protect loss of perennial meristems from wave action and conserve energy and nutrients within the beds (Kenworthy \& Thayer 1984, Stevenson 1988). Nevertheless, other factors such as the modifying effect of the sedimentary environment on biomass ratios should be considered in future studies when determining phenological indices in Cymodocea nodosa (cf. also Zieman \& Wetzel 1980)

The less pronounced seasonal differences in dry weight of the longest leaves when compared to the change in leaf length only (see Fig. 4) can at least in part be attributed to changing leaf width. Moreover, a change in leaf thickness, as reported for Cymodocea nodosa (Pirc unpubl.) and other seagrasses (Hamburg \& Homann 1986), was also observed in our study. Maximum leaf thickness in late winter and early spring might explain the relative high leaf dry weight during this period.

Maximum LAI at Stn R1 was about twice as high as reported for Cymodocea nodosa stands in France (Caye \& Meinesz 1985) and in the Gulf of Naples (Pirc unpubl.). Nevertheless, the values are well within the range reported for other temperate seagrass species such as Zostera marina (Kentula \& McIntire 1986) and Posidonia oceanica (Drew 1978).

The higher $\mathrm{N}$-content in leaf material of Cymodocea nodosa when compared to the other plant organs is in agreement with the results of Pirc \& Wollenweber (1988), who hypothesize N-storage in Cymodocea nodosa leaves.

\section{Production}

The number of leaves produced per shoot per year is within the range reported by Caye \& Meinesz (1985) but somewhat lower than that observed by Pirc (unpubl.), who counted about 13 leaves per shoot per year in a meadow at Ischia (Gulf of Naples). This might indicate a shorter growth period in the more northern areas of distribution (Cote d'Azur, Gulf of Trieste).

Leaf production expressed as $g$ dry wt $\mathrm{m}^{-2} \mathrm{~d}^{-1}$ was well within the range reported for many other seagrass species such as Posidonia australis, $P$. oceanica, Thalassia testudinum, Zostera marina and Heterozostera tasmanica (for comprehensive reviews consult Zieman \& Wetzel 1980, Stevenson 1988). The productivity value for Cymodocea nodosa given by Zieman \& Wetzel (1980) is misleading since the original work by Gessner \& Hammer (1960) refers to a mixed Caulerpa-Cymodocea association. Moreover, these NPP rates are most probably erratic since they are based solely on 2 measurements conducted with Caulerpa only, i.e. the productivity of $C$. nodosa was estimated. Furthermore, this method yielded exceptionally high values which, to our knowledge, have otherwise never been reported for any submersed seagrass species.

A comparison of annual total NPP as estimated by the 3 different approaches is presented in Table 7. At Stn R1 the 2 applied techniques provided very similar results. The NPP estimate obtained by the $\mathrm{O}_{2}$-method (performed only at Stn R2) was roughly $10 \%$ lower than the marking technique value, whereas at Stns R2 and R3 the leaf scar method yielded ca $30 \%$ higher results than the marking technique. Among the many possible explanations for these deviations, to us the most likely source of error appears to be the translation of short-term rates measured with the marking ( 1 to 2 wk) and the $\mathrm{O}_{2}$-method ( 1 to $2 \mathrm{~d}$ ) into yields over much longer periods with changing conditions (see also Zieman \& Wetzel 1980, Lipkin et al. 1986).

Despite the fact that the calculation of annual production based on the $\mathrm{O}_{2}$-method yielded the lowest results, the seasonal pattern of productivity from this method was well correlated with that from the marking technique. In Fig. 7 this seasonal pattern is presented for Stn R2, assuming a rhizome-root production during the growing period equal to $20 \%$ of the respective seasonal leaf production rates obtained by the marking technique. The $\mathrm{O}_{2}$-method appears to be more sensitive for very low winter production rates, when the other techniques failed to detect any production. These low NPP rates could be attributed to leaf thickening during winter, as supported by our seasonal dry weight determinations on leaf material. The significant correlation ( $\mathrm{r}=0.97 ; \mathrm{p}=0.001)$ between the 2 methods presented in Fig. 7 resulted in the linear regression equation

$$
\mathrm{y}=-0.31+1.523 \mathrm{x}
$$

where $y=\operatorname{NPP}$ ( $g$ dry wt $\mathrm{m}^{-2} \mathrm{~d}^{-1}$ ) obtained by the marking technique; $\mathrm{x}=\mathrm{NPP}$ determined by the $\mathrm{O}_{2}$ method. 
Although we agree with Kemp et al. (1986) that each technique has its strength and weakness, our results indicate that each of the 3 methods can provide reasonable estimates for NPP in Cymodocea nodosa. Nevertheless, a possible underestimation of peak production by the $\mathrm{O}_{2}$-method should be taken into consideration. In order to obtain reliable extrapolations of short-term rates to annual yields, a high number of replicated measurements is strongly recommended. It also should be emphasized that the marking technique as well as the $\mathrm{O}_{2}$-method can provide production rates beside the estimate of annual yields; the leaf scar method can only give a yield of production.

Each method should be chosen according to the parameter of interest (yield or rate aspect) and to the time, equipment and facilities of the investigator. Whereas the marking technique needs much diving work, the leaf scar method can, except for the harvesting procedure, be conducted in the laboratory.

Assuming a similar biomass pattern throughout the Gulf of Trieste - supported by observations made by Simonetti (1973) - an average (i.e. mean of the results in Table 7, assuming equal root productions at Stns R2 and R3) areal NPP of $618.4 \mathrm{~g}$ dry wt $\mathrm{m}^{-2} \mathrm{yr}^{-1}$ (corresponds to $292.6 \mathrm{~g} \mathrm{C}$ and $11.6 \mathrm{~g} \mathrm{~N} \mathrm{~m}^{-2} \mathrm{yr}^{-1}$ ) is suggested for Cymodocea nodosa in this part of the Adriatic Sea.

The average maximum total biomass (including rhizomes and roots) of $555 \mathrm{~g}$ dry wt $\mathrm{m}^{-2}$ turned over 1.1 times per year, whereas the turnover rate of only leaf material (based on maximum LSC) was about 3 crops of leaves per year. Based on a rough estimate of $1 \mathrm{~km}^{2}$ Cymodocea nodosa cover within the Bay of Piran (Peduzzi unpubl.), an annual NPP of more than 600 tons of plant dry mass can be expected.

It can be concluded that Cymodocea nodosa may significantly contribute to the overall production of organic material in the Northern Adriatic Sea.

Acknowledgements. The field assistance of F. Kravos, J. Forte und $\mathrm{V}$. Bernetic is gratefully acknowledged. We thank G. J. Herndl and $\mathrm{H}$. Pirc for valuable discussions, J. A. Ott for providing laboratory space and $\mathrm{S}$. Neulinger for drawing the figures. The opportunity of using the coring device of $\mathrm{H}$. Pirc and the performance of $\mathrm{C} / \mathrm{N}$ analyses by $\mathrm{A}$. Gunatilaka is acknowledged. This work was supported by the Emil Boral Foundation and by the Austrian Science Foundation (FWF project P7009) to P. Peduzzi.

\section{LITERATURE CITED}

Avcin, A., Meith-Avcin, N., Vukovič, A., Vriser, B. (1974). A comparison of benthic communities of Strunjan and Koper Bays with regard to their differing exposure to pollution stress. Biol. vestn. (L.jubljana) 22: 171-208

Benovic, A., Justic, D., Bender, A. (1987). Enigmatic changes in the hydromedusan fauna of the northern Adriatic Sea. Nature, Lond. 326: 597-600
Bittaker, H. F., Iverson, R. L. (1976). Thalassia testudinum productivity: a field comparison of measurement methods. Mar. Biol. 37: 39-46

Bornet, E. (1864). Recherches sur le Phucagrostis major Cavol. Ann. Sci. nat., Bot. Ser. 5, 1: 5-51

Brouns, J. J. W. M. (1985). A comparison of the annual production and biomass in three monospecific stands of the seagrass Thalassia hemprichii (Ehrenb.) Aschers. Aquat. Bot. 23: $149-175$

Caye, G., Meinesz, A. (1985). Observations on the vegetative development, flowering and seeding of Cymodocea nodosa (Ucria) Ascherson on the Mediterranean coasts of France. Aquat. Bot. 22: 277-289

Conover, J. T. (1968). The importance of natural diffusion gradients and transport of substances related to benthic marine plant metabolism. Botanica mar. 11: 1-9

Degobbis, D., Smodlaka, N., Pojed, I., Skrivanic, A., Precali, R. (1979). Increased eutrophication of the Northern Adriatic Sea. Mar. Pollut. Bull. 10: 298-301

de la Cruz, A. A., Hackney, C. T. (1977). Energy value, elemental composition and productivity of belowground biomass of a Juncus tidal marsh. Ecology 58: 1165-1170

Den Hartog, C. (1970). The seagrasses of the world. NorthHolland, Amsterdam

Drew, E. A. (1978). Factors affecting photosynthesis and its seasonal variation in the seagrasses Cymodocea nodosa (Ucria) Aschers., and Posidonia oceanica (L.) Delile in the Mediterranean. J. exp. mar. Biol. Ecol. 31: 173-194

Gallagher, J. L., Plumley, F. G. (1979). Underground biomass profiles and productivity in Atlantic coastal marshes. Am. J. Bot. 66: 156-161

Gessner, F., Hammer, L. (1960). Die Primärproduktion in mediterranen Caulerpa-Cymodocea-Wiesen. Botanica mar. 2: 157-163

Hackney, C. T., Hackney, O. P. (1978). An improved, conceptually simple technique for estimating the productivity of marsh vascular flora. Gulf Res. Rep. 6: 125-129

Hackney, C. T., de la Cruz, A. A. (1986). Belowground productivity of roots and rhizomes in a giant cordgrass marsh. Estuaries 9: 112-116

Hamburg, S. P., Homann, P. S. (1986). Utilization of growth parameters of eelgrass, Zostera marina, for productivity estimation under laboratory and in situ conditions. Mar. Biol. 93: 299-303

Hartmann, R. T., Brown, D. L. (1967). Changes in internal atmosphere of submersed vascular hydrophytes in relation to photosynthesis. Ecology 48: 252-258

Herndl, G. J., Peduzzi, P. (1988). The ecology of amorphous aggregations (marine snow) in the Northern Adriatic Sea: I. General considerations. P.S.Z.N.I.: Mar. Ecol. 9: 79-90

Herndl, G. J., Peduzzi, P., Fanuko, N. (1989). Benthic community metabolism and microbial dynamics in the Gulf of Trieste (Northern Adriatic Sea). Mar. Ecol. Prog. Ser. 53: 169-178

Hopkinson, C. S., Gosselink, J. G., Parrondo, R. T. (1978). Aboveground production of seven marsh plant species in coastal Louisiand. Ecology 59: 760-769

Jones, J. A. (1968). Primary productivity of the tropical marine turtle grass Thalassia testutinum König and its epiphytes. Ph.D. thesis, University of Miami

Justic, D. (1988). Trend in the transparency of the Northern Adriatic Sea 1911-1982. Mar. Pollut. Bull. 19: 32-35

Kemp, W. M., Lewis, M. R., Jones, T. (1986). Comparisons of methods for measuring production by the submersed macrophyte, Potamogeton perfoliatus L. Limnol. Oceanogr. 31 1322-1334

Kemp, W. M., Murray, L., Borum, J., Sand-Jensen, K. (1987). 
Diel growth in eelgrass Zostera marina. Mar. Ecol. Prog. Ser. 41: 79-86

Kentula, M. E., McIntire, C. D. (1986). The autecology and production dynamics of eelgrass (Zostera marina L.) in Netarts Bay, Oregon. Estuaries 9: 188-199

Kenworthy, W. J., Thayer, G. W (1984). Production and decomposition of the roots and rhizomes of seagrasses, Zostera marina and Thalassia testudinum, in temperate and subtropical marine ecosystems. Bull. mar. Sci. 5: 364-379

Lipkin, Y., Beer, S., Best, E. P. H., Kairesalo, T., Salonen, K. (1986). Primary production of macrophytes: terminology, approaches and a comparison of methods. Aquat. Bot. 26: $129-142$

McRoy, C. P. (1974). Seagrass productivity: carbon uptake experiments in eelgrass, Zostera marina. Aquaculture 4: $131-137$

McRoy, C. R., McMillan, C. (1977). Production ecology and physiology of seagrasses. In: McRoy, C. P., Helfferich, C. (eds.) Seagrass ecosystems: a scientific perspective. Marcel Dekker, New York, p. 53-87

Murray, K., Wetzel, R. L. (1987). Oxygen production and consumption associated with the major autotrophic components in two temperate seagrass communities. Mar. Ecol. Prog. Ser. 38: 231-239

Nixon, S. W., Oviatt, C. A. (1972). Preliminary measurements of midsummer metabolism in beds of eelgrass, Zostera marina. Ecology 53: 150-153

Ott, J. A. (1980). Growth and production in Posidonia oceanica (L.) Delile. P.S.Z.N.I: Mar. Ecol. 1: 47-64

Patriquin, D. G. (1973). Estimation of growth rate, production, and age of the marine angiosperm Thalassia testudinum König. Caribb. J. Sci. 13: 111-121

Petersen, C. G. J. (1918). The seabottom and its production of food. Rep. Dan. Biol. Stn 25: 1-62

Pirc, H., Wollenweber, B. (1988). Seasonal changes in nitrogen, free amino acids, and $\mathrm{C} / \mathrm{N}$ ratio in Mediterranean seagrasses. P.S.Z.N.I: Mar Ecol. 9: 167-179

Ranke, U. (1976). The sediments of the Gulf of Piran (Northern Adriatic Sea). Senckenbergiana marit. 8: 23-60

This article was submitted to the editor
Roberts, D. G., Moriarty, D. J. W. (1987). Lacunal gas discharge as a measure of productivity in the seagrasses Zostera capricorni, Cymodocea serrulata and Syringodium isotifolium. Aquat. Bot. 28: 143-160

Sand-Jensen, K. (1975). Biomass, net production and growth dynamics in an eelgrass (Zostera marina L.) population in Vellerup Vig. Denmark. Ophelia 14: 185-201

Schubauer, J. P., Hopkinson, C. S. (1984). Above- and belowground emergent macrophyte production and turnover in a coastal marsh ecosystem, Georgia. Limnol. Oceanogr 29: $1052-1065$

Simonetti, G. (1973). I consorzi a fanerogame marine nel Golfo di Trieste. Atti Ist. veneto Sci. Lett. Arti 181: 459-502

Smith, K. K., Good, R. E., Good, N. F. (1979). Production dynamics for above- and belowground components of a New Jersey Spartina alterniflora tidal marsh. Estuar. coast. mar. Sci. 9: 189-201

Stachowitsch, M. (1986). The Gulf of Trieste: a sensitive ecosystem. Nova Thalassia 8: 221-235

Stevenson, J. C. (1988). Comparative ecology of submersed grassbeds in freshwater, estuarine, and marine environments. Limnol. Oceanogr. 33: 867-893

Svoboda, A., Ott, J. A. (1983). In situ measurement of community metabolism in littoral marine systems. In: Gnaiger, E., Forstner, H. (eds.) Polarographic oxygen sensors. Springer-Verlag, Berlin, p. 285-297

Tomlinson, P. B. (1974). Vegetative morphology and meristem dependence - the foundation of productivity in seagrasses. Aquaculture 4: 107-130

Vollenweider, R. A. (ed.) (1969). A manual on methods for measuring primary production in aquatic environments. IBP Handbook No. 12. Blackwell Scientific Publishers, Oxford

Zieman, J. C. (1974). Methods for the study of growth and production of turtle grass Thalassia testudinum. Aquaculture $4: 139-143$

Zieman, J. C., Wetzel, G. (1980). Productivity in seagrasses: methods and rates. In: Phillips, R. C., McRoy, C. P. (eds.) Handbook of seagrass biology. Garland, New York, p. $87-116$

Manuscript first received: September 21, 1989

Revised version accepted: April 4, 1990 